\title{
Primary failure of eruption (PFE)
}

\author{
Upendra Jain, ${ }^{1}$ Amitabh Kallury, ${ }^{2}$ Dinesh Dathu Rao, ${ }^{3}$ Harsh Vibhor Bharti ${ }^{4}$
}

${ }^{1}$ Department of Orthodontics, People's College of Dental Sciences and Research Centre, Bhopal, Madhya Pradesh, India ${ }^{2}$ Department of Orthodontics, People's Dental Academy, Bhopal, Madhya Pradesh, India ${ }^{3}$ Department of Orthodontics,

SJM Medical College \& Hospital, Chitradurga,

Karnataka, India

${ }^{4}$ Department of Orthodontics, Rishiraj College of Dental Sciences \& Research Centre, Bhopal, Madhya Pradesh, India

\section{Correspondence to}

Dr Upendra Jain,

bracesuppujain@gmail.com

Accepted 11 March 2015

\section{DESCRIPTION}

A 15-year-old boy presented with difficulty chewing. Clinical examination revealed a bilateral posterior open bite with anterior deep bite and multiple submerged posterior teeth (figures 1-3). OPG (orthopantomogram) X-ray revealed submerged premolars and molars, in absence of ankylosis or other mechanical obstruction (figure 4). The case was diagnosed as primary failure of eruption (PFE). PFE is a non-syndromic eruption disorder where the permanent teeth fail to erupt in the absence of any mechanical obstruction. ${ }^{1}$ In these cases, even though resorption of the alveolar bone and the roots of the deciduous teeth is normal, the permanent teeth do not follow the eruption path. The posterior teeth are more frequently affected. This condition manifests as a posterior open bite, which increases with time despite normal vertical facial growth.

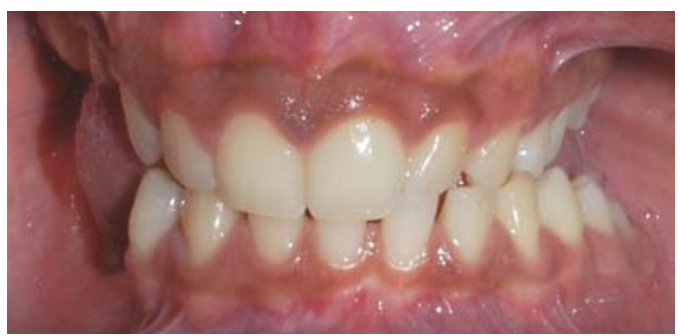

Figure 1 Intraoral photographs.

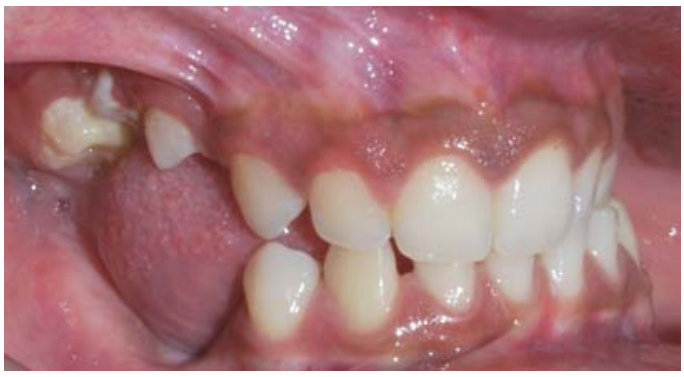

Figure 2 Intraoral photographs.

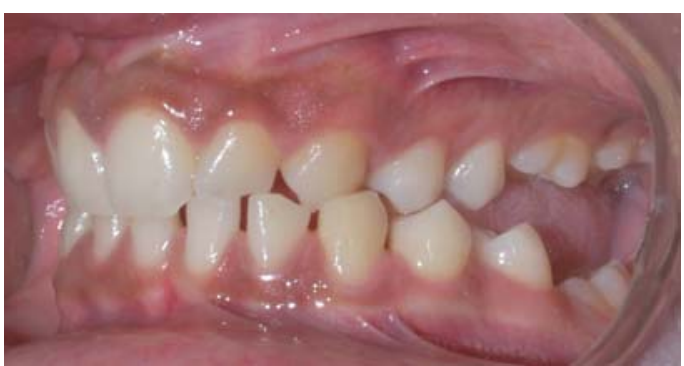

Figure 3 Intraoral photographs.

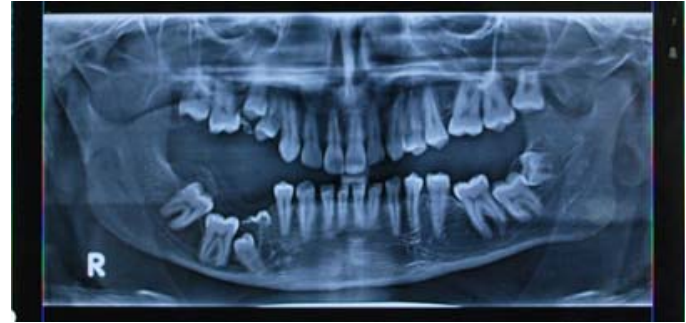

Figure 4 Orthopantomogram (OPG).

The aetiology of PFE is not known, however, genetic disturbances associated with mutations in parathyroid hormone receptor 1 (PTH1R) have been implicated. ${ }^{2}$

Diagnosis should rule out mechanical failure of eruption (MFE) due to any obstruction in the path of eruption from retained deciduous teeth, supernumerary teeth or fibrous gingiva. Genetic analysis of PTH1R confirms PFE.

Teeth with PFE are unresponsive to orthodontic mechanics and ankylose when subjected to orthodontic force. ${ }^{1}$ Prosthetic rehabilitation is the only viable treatment option in these patients. Surgical procedures such as distraction osteogenesis (DO) or segmental osteotomy are useful treatment options; however, their use in routine practice is limited due to the associated complications.

\section{Learning points}

- Primary failure of eruption is a rare non-syndromic condition where the erupted posterior teeth are submerged, in the absence of mechanical obstruction, resulting in posterior open bite.

- The teeth do not respond to orthodontic treatment and therefore the affected teeth cannot be moved into their correct positions.

- Prosthetic rehabilitation is necessary to achieve good posterior occlusion.

Competing interests None.

Patient consent Obtained.

Provenance and peer review Not commissioned; externally peer reviewed.

\section{REFERENCES}

1 Proffit WR, Vig KWL. Primary failure of eruption: a possible cause of posterior open bite. Am J Orthod 1981;80:173-90.

2 Decker E, Stellzig-Eisenhauer A, Fiebig BS, et al. PTHR1 loss-of-function mutations in familial, nonsyndromic primary failure of tooth eruption. Am J Hum Genet 2008;83:781-6. 


\section{Images in...}

Copyright 2015 BMJ Publishing Group. All rights reserved. For permission to reuse any of this content visit http://group.bmj.com/group/rights-licensing/permissions.

BMJ Case Report Fellows may re-use this article for personal use and teaching without any further permission.

Become a Fellow of BMJ Case Reports today and you can:

- Submit as many cases as you like

- Enjoy fast sympathetic peer review and rapid publication of accepted articles

- Access all the published articles

- Re-use any of the published material for personal use and teaching without further permission

For information on Institutional Fellowships contact consortiasales@bmjgroup.com

Visit casereports.bmj.com for more articles like this and to become a Fellow 